\title{
HISTORY OF ART
}

\section{O. HANSEN VIRTUAL MUSEUM AS AN ATTEMPT TO RECONSTRUCT THE THIRD STATE MUSEUM}

\section{Hanna Reshetnova ${ }^{1}$}

DOI: https://doi.org/10.30525/978-9934-26-076-6-10

In the XX century first quarter there were three state museums in Kyiv city. Two of them, although subjected to some transformation, survived to present date. The Third State Museum, whose funds mostly represented the collection of Oscar Hermann Hansen, nationalized in 1919, was scattered and effectively deleted from the country's history. The museum virtual reconstruction is purposed to demonstrate masterpieces that were kept in the former private collection, and now are in various Ukrainian museums' collections.

Oskar Herman Hermanovych Hansen is a well-known fine arts collector and connoisseur, whose collection, at the XX century beginning, was estimated at about five million rubles and included paintings by old and modern artists, graphic works, decorative and applied artworks, church rituals items, arms, etc. [3, p. 1-3]. Whilst turbulent revolution and regime change period O. Hansen handed over his collection to the state and «disappeared» from the historians' view field. Over time, the museum was disembodied: a significant part of art works became the basis for N. Onatsky Regional Art Museum in Sumy [1, p. 2-5], another artifacts replenished collections of museums in Kyiv, Sumy, Kharkiv, Odessa and other cities.

Mykhailo Pavlovych Denysov, who kept the inventory records and registered the museum's objects, noted in one of his memos: «If merging all artwork that O. G. Hansen collected, that is, the Kyiv and Sumy parts of his collection, into a single whole, as it was earlier..., then we would get a firstclass museum, a one of really state significance...» [7, p. 135-136]. However, the authorities decided to replenish regional museums and abandoned the idea of returning all the works to Kyiv.

Now the archives opened, and receipt books, museum inventory books, and other sources of information freely accessible [6], we can identify artworks that previously belonged to O. Hansen collection and were placed initially at the Third State Museum. Given that now the accessible physical world circle is narrowing around a person in fact limiting the existence area to

\footnotetext{
${ }^{1}$ National Academy of Fine Arts and Architecture, Ukraine
} 
virtual world built by electronic devices, the museum reconstruction is not just simply possible, but already necessary is to create it in a virtual dimension, in the spirit and at the behest of the time realities.

The main task when creating the Digital Third State Museum named after O. Hansen is to develop the most concise and accessible site structure. The museum main sections are formed with the account of collection directions: «Painting», «Graphics», «Decorative and applied arts», «Furniture», «Arms», «Numismatics, faleristics, sphragistics», "Church ritual objects» and «Cult objects». There will be separate blocks featuring the "Library», where it is supposed to exhibit books from the collection of O. Hansen (found in the National Museum «Kyiv Art Gallery», the National Museum of Arts named after Bohdan and Varvara Khanenko, the private collection in Sumy city), the information about this museum founder and about the project and «Educational lectures» section.

Each of these art sections will include illustrations imaging objects (exhibits) with their full description (exhibit passport): author, title, year and place of creation, technique and material, size, links to the current location with the inventory account number, additional data. In cases when the artwork data available its location is not properly established, the partially filledin pages will be created, which will allow historians, art historians, and museum employees to identify the artwork and possibly find it.

The artworks photos will be produced by the virtual museum founders, or, when inaccessible, can be provided by the institutions or persons currently keeping as stored these artworks. It is advisable to provide for the possibility of viewing three-dimensional exhibits from several angles or as a 3D model made by gradually moving the camera along 360 degrees orbit around the object or rotating the object around its axis with a fixed camera position.

A significant advantage of a virtual museum consists in the opportunity to present not only classical museum labels we used to seeing under artworks in real museums, but also to take advantage of the United States experience and place several «labels» with comments from specialists in various fields: art historians, ethnographers, historians, etc. [5, p. 15]. Additional data retrievable can include both scientific educational and journalistic materials related to the exhibit. The supplementing materials can be presented in various formats: text, photos, videos and audio materials, etc. Thus, thanks to different viewpoints and research methods, the virtual museum will expand and strengthen the educational function that a museum institution does obligatorily bear in the modern world. Quoting D. Belkevych: «In the XXI century, a museum no longer has the right to be a building with four walls. A museum is primarily a source of information, a content-provider» [2, p. 152].

As for language localization, the content should be presented in the state language Ukrainian; still the needs of modern society require the presence of 
an English version, which will contribute to a broader presentation of the museum and to establish reliable and strong international contacts. Upon the virtual museum foreign audience visits analysis conducting, the need for exhibition support in other languages will become clear.

Based on the above, we understand that the virtual museum has a number of advantages: the world community acquaintance with art works located in Ukraine; the ability to remotely visit the museum at a convenient time from anywhere on the planet; and the museum's inclusive policy. Another advantage a virtual museum offers is the free choice of content viewed by a visitor, the absence of «exhibition-long moving path», so often required to be observed in ordinary museums [5, p. 15]. «The database search opportunities and query processing are just something fundamentally new that only modern information technologies can provide» [4, p. 16-17].

The revival and reconstruction of $\mathrm{O}$. Hansen's collection in the form of a virtual museum is not only just a web resource development with its materials inclusion into the global information space, but also it embodies the unification of the museum and scientific community in order to demonstrate the heritage collected by a private collector on the territory of our country and mercilessly dispersed by the Soviet authorities. Now, never intruding into the existing museum collections, a hundred years after its foundation, we can finally restore the Third State Museum.

\section{References:}

1. Arkhivni naukovi fondy rukopysiv ta fonozapysiv In-tu mystetstvoznavstva, fol'klorystyky ta etnolohiyi im. M. T. Ryl's'koho NAN Ukrayiny [Archive scientific funds of manuscripts and audio recordings of M.T. Rylskyi Institute of Art Studies, Folklore and Ethnology of the National Academy of Sciences of Ukraine].

2. Belkevych D. (2011) Muzei yak content-provider: IT u vystavkovomu prostori [Museum as a content-provider: IT in the exhibition space]. Art Ukraine, no. 1(20), pp. $152-155$.

3. Instytut rukopysu Natsional'noyi biblioteky Ukrayiny imeni V. I. Vernads'koho (IR NBUV) [Institute of Manuscript of V.I. Vernadskyi National Library of Ukraine (IM VNLU)].

4. Koshcheeva E. (2006) Ne trepat' veshch' ponaprasnu. Avtomatizirovannye informatsionnye sistemy v muzeyakh [Do not wear out things in vain. Automated information systems in museums]. Mir muzeynykh tekhnologiy, vol. June, pp. 16-17.

5. Norris L. (2013) Ukrainski muzei: pohliad z SShA [Ukrainian museums: a view from the USA]. Prostir. Museum, no. 2(8), pp. 12-15.

6. Pamiętnik ilustrowany wystawy obrazów I dzieł dawnej sztuki (1915) Kijów: Nakladem Komitetu Wystawy.

7. Tsentral'nyy derzhavnyy arkhiv vyshchykh orhaniv vlady ta upravlinnya Ukrayiny [Central State Archive of Central Executive and Administrative Bodies of Ukraine]. 